\title{
Soil Carbon and Nutrient Changes Associated with Deforestation for Pasture in Southern Costa Rica
}

\author{
Timothy Huth ${ }^{1}$, Stephen Porder ${ }^{2,5}$, Joaquin Chaves ${ }^{3}$, and Jessica H. Whiteside ${ }^{4}$ \\ ${ }^{1}$ Center for Environmental Studies, Brown University, Providence, Rhode Island, 02912, U.S.A. \\ ${ }^{2}$ Department of Ecology and Evolutionary Biology, Brown University, Providence, Rhode Island, 02912, U.S.A. \\ ${ }^{3}$ NASA Goddard Space Flight Center, Greenbelt, Maryland, 20771, U.S.A. \\ ${ }^{4}$ Department of Geological Sciences, Brown University, Providence, Rhode Island, 02912, U.S.A.
}

\section{ABSTRACT}

We assessed the effects of deforestation on soil carbon $(C)$ and nutrient stocks in the premontane landscape near Las Cruces Biological Station in southern Costa Rica, where forests were cleared for pasture in the mid-1960s. We excavated six soil pits to a depth of $1 \mathrm{~m}$ in both pasture and primary forest, and found that $\mathrm{C}$ stocks were $\sim 20 \mathrm{~kg} \mathrm{C} / \mathrm{m}^{2}$ in both settings. Nevertheless, soil $\delta^{13} \mathrm{C}$ suggests $\sim 50$ percent of the forest-derived soil $\mathrm{C}$ above $40 \mathrm{~cm}$ depth has turned over since deforestation. Soil nitrogen $(\mathrm{N})$ and phosphorus $(\mathrm{P})$ stocks derived from the soil pits were not significantly different between land uses $(P=0.43$ and 0.61 , respectively). At a larger spatial scale, however, the ubiquity of ruts produced by cattle-induced erosion indicates that there are substantial soil effects of grazing in this steep landscape. Ruts averaged $13 \mathrm{~cm}$ deep and covered $\sim 45$ percent of the landscape, and thus are evidence of the removal of $0.7 \mathrm{Mg} \mathrm{C} /$ ha/yr, and 70, 9 and $40 \mathrm{~kg} / \mathrm{ha} / \mathrm{yr}$ of N, P and potassium $(\mathrm{K})$, respectively. Subsoils in this region are 10 times less C- and N-rich, and $\sim 2$ times less $\mathrm{P}$ - and K-rich than the topsoil. Thus, rapid topsoil loss may lead to a decline in pasture productivity in the coming decades. These data also suggest that the soil $\mathrm{C}$ footprint of deforestation in this landscape may be determined by the fate of soil $\mathrm{C}$ as it is transported downstream, rather than $\mathrm{C}$ turnover in situ.
Abstract in Spanish is available in the online version of this article
Key words: cattle; deforestation; nutrients; pasture; soil carbon; terracettes.

Tropical forests are being Cleared at unPRECEDENTED Rates, driven largely by the demand for food from an increasing population, changing diets, and economic development (Smith et al. 2007, DeFries et al. 2010). Tropical deforestation has accounted for $\sim 60$ percent of global emissions due to land-use change since 1850 (Houghton 2003), and today constitutes $\sim 15$ percent of current anthropogenic emissions (Houghton 2007). In Central and South America, deforestation is largely driven by pasture and agricultural expansion, and in many regions these practices operate with minimal (if any) fertilizer addition. With low inputs, land degradation post-deforestation can be rapid (McGrath et al. 2001), and as nutrient losses come to constrain production, there is an incentive to clear more land (Serrão et al. 1996). Within this context, however, there is considerable variation in outcome given the large differences in soil fertility across the tropics (Sanchez 1976).

The replacement of productive forests by agriculture or pasture results in substantial carbon (C) emissions from aboveground biomass. In contrast, recent meta-analyses find relatively small effects on soil C (e.g., Powers et al. 2011), with large variance around the mean effect of a particular transition (e.g., forest to pasture). High spatial heterogeneity in both rainfall and soil type, and clustering of studies in particular regions, preclude a

Received 4 August 2011; revision accepted 26 November 2011.

${ }^{5}$ Corresponding author; e-mail: stephen_porder@brown.edu robust extrapolation of these results to the tropics as a whole (Powers et al. 2011). Furthermore, many studies report data from the shallow soil (often $<30 \mathrm{~cm}$ depth e.g., Schedlbauer \& Kavanagh 2008), which may not capture the integrated effects throughout the soil column (Veldkamp 1994, Guo \& Gifford 2002). Perhaps more concerning, most studies focus on changes in carbon concentration, which is only relevant to global change if bulk density is measured accurately (which is uncommon); otherwise compaction in pastures may lead to a substantial overestimate of soil carbon content (Veldkamp et al. 2003). Finally, it is important to note, however, that even pools of soil $\mathrm{C}$ with no net change may be turning over, as demonstrated by heavier stable isotope signatures $\left(\delta^{13} \mathrm{C}\right)$ in pasture soils where grasses utilizing C4 photosynthesis have replaced C3 forest vegetation (Veldkamp 1994). Thus, our understanding of changes in soil C stocks associated with forest conversion to pasture bears further consideration, and is one of the foci of this article.

Land-use change in the tropics can also have significant effects on soil fertility and aboveground productivity (Davidson et al. 2004), and many tropical grazing operations run measureable nutrient deficits (Smaling et al. 1997, MacDonald et al. 2011). Nutrient budgets, however, are difficult to scale up to the landscape (Fearnside 1980, Smaling et al. 1997, Hartemink, 2006), in part because of poorly constrained estimates of soil erosion (Davidson et al. 2004, Lal 2009). Even where erosion has been considered, the majority of studies have focused on relatively 
stable tectonic settings with low inherent soil fertility and very low erosion rates, such as sub-Saharan Africa and the Amazon basin (McGrath et al. 2001, Sanchez 2002). Studies of nutrient stock changes associated with deforestation for pasture are rare in the montane tropics, where erosion rates are likely to be higher.

In this context we measured changes in total soil carbon $(\mathrm{C})$, nitrogen $(\mathrm{N})$, phosphorus $(\mathrm{P})$, and potassium $(\mathrm{K})$ associated with deforestation for pasture in the premontane forests near Las Cruces Biological Station in Southern Costa Rica. We worked at two spatial scales. First, we excavated multiple soil pits and we measured soil $\mathrm{C}, \mathrm{N}, \mathrm{P}$, and $\mathrm{K}$ content in a primary forest and pasture cleared $\sim 50 \mathrm{yr}$ ago. We used $\delta^{13} \mathrm{C}$ of the soil and forest and pasture vegetation to assess how much of the soil $\mathrm{C}$ stock has turned over since deforestation. At a larger spatial scale, we quantified topsoil erosion and $\mathrm{C}, \mathrm{N}, \mathrm{P}$, and $\mathrm{K}$ exported from a network of extensive cattle ruts that cut across these steep pastures.

\section{METHODS}

Site DESCRIPTION.-We worked in and around Las Cruces Biological Station in Coto Brus County, southern Costa Rica in 20092010 (Fig. S1). The station has a mean annual temperature of $21^{\circ} \mathrm{C}$, and mean annual rainfall is $\sim 4000 \mathrm{~mm} / \mathrm{yr}$, with a pronounced dry season $(<100 \mathrm{~mm} / \mathrm{mo})$ from December to April. The study area is in the foothills of the Zapote range at an altitude of $1200-1300 \mathrm{~m}$, and is dominated by steep topography $\left(>20^{\circ}\right.$ in many places). Soils are mostly Lithic and Andic Dystrudepts along with Typic Hapludands (Jin et al. 2000) derived from basaltic andesite and associated volcanics. The region hosted premontane tropical forest until the mid-20th century, when rapid deforestation began, and it is now dominated by pasture and small agricultural holdings. Primary forest remains in patches, of which Las Cruces is one.

We selected sites adjacent to Las Cruces Biological Station that were converted directly from forest to pasture in the $1960 \mathrm{~s}$ and remained actively grazed pasture until the station purchased the 26 ha property in 2008 (Z. Zahawi, pers. comm.). Vegetation was not burned after clearing and we found no evidence of charcoal while sampling soils. These pastures were seeded soon after deforestation, and such 'low-investment systems' are typically not fertilized (Jin et al. 2000). The pastures are now dominated by Axonopus micay and Urochloa mollis, both C4 grasses of Neotropical origin.

ANALYSES: SoILs.-In August 2009, we excavated 12 soil pits, six in pasture and six in forest, arrayed across $\sim 600 \mathrm{~m}$ of both land use types. Pasture pits were located on a single 26 ha parcel of land adjacent to the forest. We sampled on three separate ridges and slopes, and all pasture pits were within $200 \mathrm{~m}$ of the forest edge. Likewise, all forest pits were located within one continuous parcel of forest (Las Cruces Biological Station), included ridge $(N=3)$ and slope $(N=3)$ positions, and were between 250 and $500 \mathrm{~m}$ from the pasture edge. We dug pits to a depth of $1 \mathrm{~m}$. Once each pit was open, we excavated a $10 \times 10 \mathrm{~cm}$ shaft down the sampling face to assess bulk density, and sampled the soils from this shaft for additional chemical analyses. The soils showed strong horizonation so we chose to sample by horizon rather than depth. Where horizons were $>20 \mathrm{~cm}$ thick we took several within-horizon subsamples at different depths and analyzed them separately, we report means by horizon below. We air-dried samples at Las Cruces and shipped homogenized subsamples back to Brown University, where they were sieved $(<2 \mathrm{~mm})$ and handpicked for roots. We split each sample into three subsamples. One was analyzed for total elements by lithium borate fusion and ICP-MS (ALS Chemex, Reno, Nevada, U.S.A.), a second for C, $\mathrm{N}$, and $\delta^{13} \mathrm{C}$ on a Costech Analytical Model 4010 (Costech Analytical Technologies, Valencia, California, U.S.A.) flash-combustion element analyzer with a Thermo Conflo III interface into a DeltaVPlus isotope ratio mass spectrometer (Thermo Scientific, West Palm Beach, Florida, U.S.A.) in the Whiteside lab at Brown University, and a third for bulk density by drying at $105^{\circ} \mathrm{C}$ for $48 \mathrm{hr}$. All results are presented on an oven dry weight basis.

We also collected leaves and litter from both pasture and forest, which were dried at $65^{\circ} \mathrm{C}$ and analyzed for $\mathrm{C}, \mathrm{N}$, and $\delta^{13} \mathrm{C}$ as described above. We calculated the contribution of $\mathrm{C} 3$ (forest) and C4 (pasture grasses) plants to soil carbon as:

$F_{\text {pastureC }}=\frac{\delta^{13} C_{\text {pasturesoil }}-\delta^{13} C_{\text {forestsoil }}}{\delta^{13} C_{\text {pasturelitter }}-\delta^{13} C_{\text {forestlitter }}}$

where $F_{\text {pastureC }}$ is the fraction of soil $\mathrm{C}$ from pasture inputs (Powers \& Veldkamp 2005). There are several complications to this approach discussed in detail by Powers and Veldkamp (2005), including the need to measure both leaf and root litter, and the presence of both C3 and C4 plants in pasture. We assumed no C3 inputs to the pasture after its creation, and did not measure the $\delta^{13} \mathrm{C}$ of roots in either forest or pasture, so our calculation of $\mathrm{F}_{\text {pasturec }}$ may be less accurate than one that takes these factors into consideration. We did correct for changes, however, in $\delta^{13} \mathrm{C}$ of forest soils with depth in our calculation of $F_{\text {pastureC. We esti- }}$ mated $\delta^{13} C_{\text {forest soil }}$ for depth $(D)$ in pasture from a third order polynomial derived from the observed relationship between $\delta^{13} C_{\text {forest soil }}$ and $D$ at our six forest soil pits $\left(R^{2}=0.74\right)$ :

$\delta^{13} C_{D}=-25.9+0.0465 D-0.000812 D^{2}+\left(3.59 \exp ^{-6}\right) D^{3}$

We then used $\delta^{13} C_{D}$ as the forest soil end member for each depth at which we calculated $F_{\text {pasturec} \text {. }}$

ANALYSES: SOIL LOSS FROM CATTLE RUTS.-Our initial observations of the landscape indicated a high density of ruts in pasture on the slopes $>20^{\circ}$ that were absent from forest slopes (Fig. S2). Such features have been noted for almost a century (Ødum 1922 quoted in Rahm 1962), and are now generally considered animal paths dubbed 'terracettes' or 'cowtours' in the geomorphic literature (Trimble \& Mendel 1995). On the pasture hillslopes near Las Cruces, ruts run approximately perpendicular to slopes, and the uphill edge of one rut is often the downhill edge of the rut 
above it, forming a hillslope that resembles a flight of stairs. We measured the dimensions of individual ruts $(N=87)$ down seven slopes, as well as the fraction of the hillslopes covered by ruts. Most ruts could be approximated as triangular cross-section cuts into the hillslope (Fig. S2), although occasionally, ruts were carved deeper, resulting in trapezoidal cross-sections. We measured the dimensions of the ruts, and calculated their mean depth relative to the original hillslope. This allowed us to estimate total soil loss associated with the ruts. We converted depth of soil loss to mass loss $\left(\mathrm{kg} / \mathrm{m}^{2}\right)$ by multiplying depth by the mean bulk density of forest soil for a given depth.

To test the hypothesis that the ruts were generated by erosion rather than compaction, we took soil cores from the upslope and downslope edge of several ruts $(0-5,5-10,10-15 \mathrm{~cm}$ depth below the rut surface). As soil percent carbon ( $\% \mathrm{C})$ decreases with depth in almost all soils (Jobbágy \& Jackson 2001), we tested our hypothesis by comparing soil $\% \mathrm{C}$ between the soils collected from the uphill and downhill edges of the ruts. If erosion was the driver of rut formation, we expected that soil at the uphill edge of ruts would exhibit characteristics of deeper soil (e.g., lower $\mathrm{C}$ concentration) than cores from downhill edge because more soil had been removed above the exposed soil near the uphill edge of the rut. In contrast, if the ruts were formed by compaction, we expected no difference in soil $\mathrm{C}$ concentration between the uphill and downhill edges of the rut.

As a second test of the hypothesis that these ruts were caused by erosion, rather than compaction, we used our calculation of rut depth (based on the dimensions of the rut) to generate an 'original' depth of each rut soil sample. We define original depth as the depth of the soil before the formation of the rut (e.g., if the rut is $10 \mathrm{~cm}$ deep at the point of sampling, and we sampled $0-5 \mathrm{~cm}$ below the surface, we assigned an 'original' depth of $12.5 \mathrm{~cm}$ ). We then used the observed relationship between soil depth and soil \%C from our soil pits (Fig. 1A) to generate an 'expected' $\% \mathrm{C}$ for the rut soils given their calculated original depth in the soil profile. This expected soil \% $\%$ should only correlate with measured $\mathrm{C}$ if the ruts were formed by erosion. Thus, we took a significant correlation between expected and measured soil $\% \mathrm{C}$ as evidence in support of this hypothesis.

STATISTICS. - Carbon, $\mathrm{N}$, and $\delta^{13} \mathrm{C}$ between forest and pasture were compared using restricted maximum likelihood estimation with land use type, depth and landscape positions as fixed effects. Comparisons between the soil $\% \mathrm{C}$ in the front and back of ruts was done using one-way ANOVA after testing data for normality (Shapario-Wilk W test; $P>0.05$ for all depths on both the uphill and downhill edges of the ruts). To calculate the expected $\% \mathrm{C}$ for a soil in a rut of a given depth (D), we fitted a first order decay function to the relationship between soil $\% \mathrm{C}$ and $\mathrm{D}$ $\left(R^{2}=0.89\right)$ such that:

$\% C=8.49 \times \exp (-0.042 \times D)+0.8$

We then calculated an expected $\% \mathrm{C}$ based on the depth of soil sampled in a particular rut plus the soil we calculated had

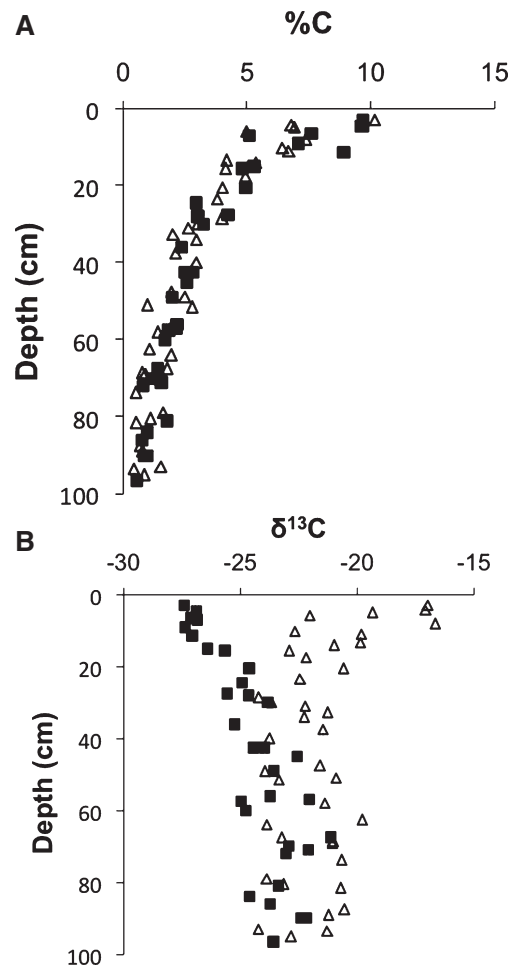

FIGURE 1. (A) Soil C concentrations; and (B) $\delta^{13} \mathrm{C}$. Filled squares are forest pits, open triangles are pasture pits.

been removed based on the geometry of the rut. Expected and measured \%C were compared by Pearson's correlation. All statistical analyses were performed in JMP (v. 8.0.2, SAS Institute, Inc. 2009; Cary, North Carolina, U.S.A.).

\section{RESULTS}

SOIL CARBON.-Carbon concentrations decreased from $\sim 10$ percent near the surface to $\sim 1$ percent at a depth of $1 \mathrm{~m}$, but did not differ between forest and pasture (Fig. 1A). Neither did bulk density (One-way ANOVA, df $=10, P=0.64$; Table S1), and thus total soil $\mathrm{C}$ stocks to a depth of $1 \mathrm{~m}$ were similar between forest and pasture $\left(P=0.79\right.$; mean $\sim 20 \pm 0.8 \mathrm{~kg} \mathrm{C} / \mathrm{m}^{2}$ for both land uses). Soil within the top $10 \mathrm{~cm}$ contained about $6.0 \mathrm{~kg} \mathrm{C} /$ $\mathrm{m}^{2}$, and soil between $90-100 \mathrm{~cm}$ depth contained $0.60 \mathrm{~kg} \mathrm{C} / \mathrm{m}^{2}$. Although the trends in soil $\mathrm{C}$ concentrations are consistent across all pits, variation in bulk density makes the total $\mathrm{C}$ content quite variable across the landscape (Table $\mathrm{S} 1$ ).

Forest $\delta^{13} \mathrm{C}$ values increased from about $-27 \%$ near the surface to between $-25 \%$ and $-21 \%$ at $1 \mathrm{~m}$ depth (Fig. 1B). In pasture, $\delta^{13} \mathrm{C}$ of bulk soil decreased from about $-17 \%$ at the surface to values indistinguishable from forest at $1 \mathrm{~m}$ depth. $\delta^{13} \mathrm{C}$ in the $\mathrm{A}$ horizon differed significantly between forest and pasture $(P<0.0001)$, but $\delta^{13} \mathrm{C}$ of deeper soils (B horizons) in both settings were not significantly different $(P=0.19)$, converging to a value of about $-23 \%$. Litter from the C3 trees in the forest has a $\delta^{13} \mathrm{C} \sim 30 \%$, whereas the $\mathrm{C} 4$ grass in pastures has 
values $\sim 12 \%$. From equations (1) and (2), the uppermost pasture soils have derived $\sim 50-60$ percent of their carbon from C4 sources since deforestation, whereas at $1 \mathrm{~m}$ depth no $\mathrm{C} 4$ carbon is detectable.

SoIL NUTRIENT CONTENT.-Soil $\mathrm{N}$ decreased with depth, from between 0.6 and 1 percent of total soil mass at the surface to about 0.1 percent at a depth of $1 \mathrm{~m}$ (Table S1). Soil $\mathrm{N}$ stocks decreased with depth from about $0.60 \mathrm{~kg} \mathrm{~N} / \mathrm{m}^{2}$ within the top $10 \mathrm{~cm}$ to $0.042 \mathrm{~kg} \mathrm{~N} / \mathrm{m}^{2}$ between 90 and $100 \mathrm{~cm}$ depth (Table S1). Total soil $\mathrm{N}$ stocks to $1 \mathrm{~m}$ did not differ between forest and pasture $\left(1.9 \pm 0.1\right.$ and $1.7 \pm 0.2 \mathrm{~kg} \mathrm{~N} / \mathrm{m}^{2}$, respectively, $\left.P=0.43\right)$. Soil $\mathrm{P}$ contents decreased from 800 to $1700 \mathrm{ppm}$ at the soil surface to about $200-1000 \mathrm{ppm}$ at $1 \mathrm{~m}$, although depth profiles were more variable than either $\mathrm{C}$ or $\mathrm{N}$ (Table $\mathrm{S} 1$ ). Mass of $\mathrm{P}$ varied between $0.076 \mathrm{~kg} \mathrm{P} / \mathrm{m}^{2}$ in the top $10 \mathrm{~cm}$ and $0.033 \mathrm{~kg} \mathrm{P} / \mathrm{m}^{2}$ at 90 $100 \mathrm{~cm}$ depth. Total $\mathrm{P}$ stocks to $1 \mathrm{~m}$ were not different between forest and pasture $\left(0.57 \pm 0.10\right.$ and $0.55 \pm 0.08 \mathrm{~kg} \mathrm{P} / \mathrm{m}^{2}$, respectively, $P=0.89$ ). Soil $\mathrm{K}$ decreased from 0.3 to 0.7 percent at the surface to about 0.15 percent at $1 \mathrm{~m}$ (Table S1). Total soil $\mathrm{K}$ stocks to $1 \mathrm{~m}$ did not differ between forest and pasture $(2.7 \pm 0.5$ and $2.1 \pm 0.1 \mathrm{~kg} \mathrm{~K} / \mathrm{m}^{2}$, respectively, $\left.P=0.35\right)$. The full soil dataset is available in the supplemental online material.

SOIL LOSS FROM CATTLE RUTS.-Although our analyses at the scale of a soil shaft $(10 \mathrm{~cm} \times 10 \mathrm{~cm} \times 1 \mathrm{~m})$ showed no differences between forest and pasture $\mathrm{C}$ and nutrient stocks, the presence of extensive ruts in the pasture suggested that the scale of a soil pit was too small to capture the relevant losses of $\mathrm{C}$ and nutrients. Ruts measured $13 \pm 0.5 \mathrm{~cm}$ deep, and over the seven measured hillslope transects extended over 45 percent of the landscape. Our observation of red B-horizon soils in the bottom of many ruts led us to postulate erosion as the rut-forming agent, which generated the expectation that soils in the uphill portion of the rut should be more similar to soils from lower in an undisturbed profile than soils from the downhill edge of the ruts. Consistent with this hypothesis, soil $\mathrm{C}$ in the $15 \mathrm{~cm}$ of soil below the rut surface was significantly lower in soils from the uphill portion of the rut (one-way ANOVA; df $=46$, $P=0.006$ ). Although this was not true of the upper $5 \mathrm{~cm}$ of rut soil (Tukey's HSD, df $=14, P>0.05$ ) it was true for both 5 -10 and $10-15 \mathrm{~cm}$ depth (Tukey's HSD, df $=14, P=0.02$ in both cases).

Using the measured geometry of the ruts, we generated an 'original' soil depth for each rut core, and used equation (3) to translate this value into an expected soil $\% \mathrm{C}$ based on the empirical relationship between forest soil $\mathrm{C}$ and depth (Fig. 1A). Expected soil $\mathrm{C}$ was significantly correlated with measured soil $\%$ $C$ in the ruts $(N=48, r=0.46, P=0.0005$; Fig. 2), further supporting the hypothesis that erosion, rather than compaction, had formed these prominent features in the landscape. When analyzing each depth interval separately, the $0-5 \mathrm{~cm}$ rut soils showed no significant correlation between predicted and observed soil $\mathrm{C}$ $(\mathrm{df}=14, r=0.09, P=0.7)$, whereas both the 5-10 and 10$15 \mathrm{~cm}$ intervals showed a strong correlation between expected

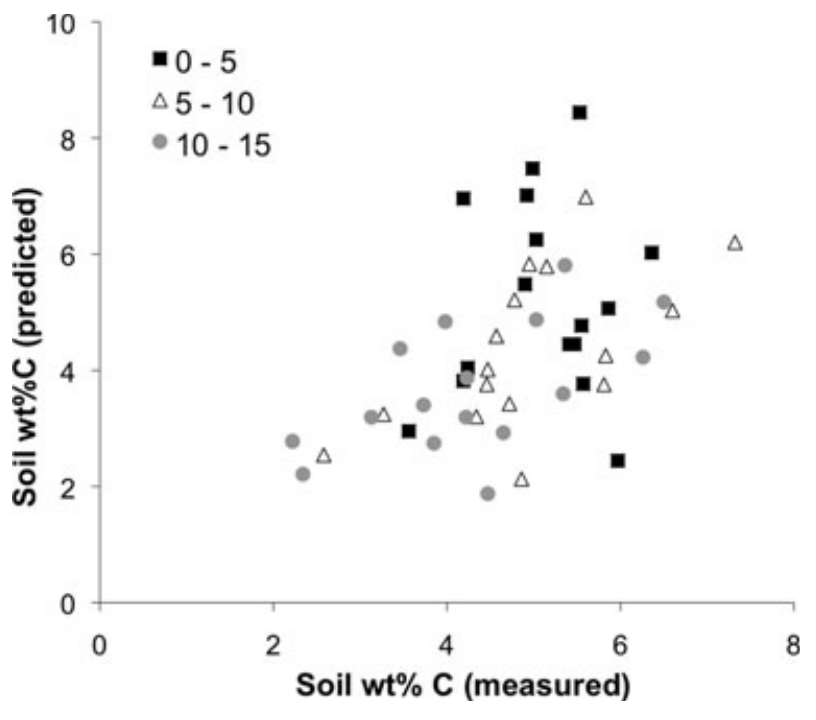

FIGURE 2. Measured soil \%C from the front and back of ruts plotted against the predicted soil $\% \mathrm{C}$ based on the relationship observed between soil $\% \mathrm{C}$ and depth in our soil pits. The overall relationship is significant $(r=0.48$, $P=0.0005$ ), but is driven by soil from 5 to 10 (open triangles, $r=0.61$, $P=0.01$ ) and 10 to $15 \mathrm{~cm}$ (gray circles, $r=0.58, P=0.02$ ) beneath the rut surface. The relationship in the $0-5 \mathrm{~cm}$ rut soil is not significant (black squares, $r=0.1, P=0.7)$.

and measured soil carbon $(r=0.62,0.58, P=0.01,0.02$, respectively, $\mathrm{df}=14$ for both).

\section{DISCUSSION}

These data suggest that the montane soils of Las Cruces hold substantially more carbon in the top $30 \mathrm{~cm}\left(\sim 13 \mathrm{~kg} \mathrm{C} / \mathrm{m}^{2}\right)$ than several other lowland tropical sites that have been intensively studied. For example, the lowland $(<100 \mathrm{~m}$ asl) soils near La Selva Biological Station in northern Costa Rica store 9.7 and $5.4 \mathrm{~kg} \mathrm{C} / \mathrm{m}^{2}$ (Veldkamp 1994), and a broader exploration of forests and pastures in the same region averaged $\sim 8 \mathrm{~kg} \mathrm{C} / \mathrm{m}^{2}-$ $30 \mathrm{~cm}$ depth (Powers \& Veldkamp 2005). Our sites are at higher elevation than those (although on similar parent material), so it is not surprising that soil $\mathrm{C}$ content is higher as well. The role of parent material and mineralogy may help explain why the soil $\mathrm{C}$ content around Las Cruces exceeds that in a similar elevation lower montane system in Ecuador, where soils contain between 8 and $10 \mathrm{~kg} \mathrm{C} / \mathrm{m}^{2}$ to a depth of $30 \mathrm{~cm}$ (Rhoades et al. 2000). In other, more highly weathered lowlands such as the Amazon, C stocks are also considerably lower. A study by Veldkamp et al. (2003) found that soil C contents at La Selva were twice as high as those reported from the Amazon basin, and stocks in Rondônia range from 2.4 to $6.2 \mathrm{~kg} \mathrm{C} / \mathrm{m}^{2}$ in the top $30 \mathrm{~cm}$ of forest soils (Neill et al. 1997). Although the soils at Las Cruces hold large stocks of C, this may not be uncommon for soils at similar elevation and derived from similar parent material. 
At the scale of a sampling shaft the soil $\mathrm{C}$ and nutrient stocks at Las Cruces appear unaltered by forest conversion to pasture. This result is consistent with a meta-analysis of carbon changes associated with deforestation in tropical forests with over $3000 \mathrm{~mm} / \mathrm{yr}$ of precipitation; indeed, many of the data in this category come from other studies in premontane Costa Rica (Guo \& Gifford 2002). Among other studies conducted in Costa Rica, Veldkamp (1994) found decreases in total soil C following conversion of forest to pasture in Atlantic Costa Rica, particularly in the top $10 \mathrm{~cm}$, but 'passive' C stocks at greater depths were more stable. In contrast, several authors have observed no significant changes in soil $\mathrm{C}$ stocks to $30 \mathrm{~cm}$ depth in pasture after deforestation across a range of pasture ages in northeastern Costa Rica (Powers \& Veldkamp 2005, Schedlbauer \& Kavanagh 2008). Powers and Veldkamp (2005) studied sites with similar annual precipitation $(4000 \mathrm{~mm})$ to Las Cruces, but which were located at lower elevations $(<750 \mathrm{~m})$ and thus had warmer temperatures (about $21-25^{\circ} \mathrm{C}$ ). They noted that despite no significant mean change between land uses, individual site changes in soil $\mathrm{C}$ stocks were variable in both sign and direction, as has been found in the Amazon (Neill et al. 1997). The lack of change in $\mathrm{C}$ stocks at Las Cruces does not preclude $\mathrm{C}$ turnover, however. $\delta^{13} \mathrm{C}$ suggests that $\sim 50$ percent of the soil $\mathrm{C}$ in the upper $40 \mathrm{~cm}$ of pasture has turned over since deforestation. Furthermore, if the loss of soil nutrients from ruts adversely affects pasture productivity, soil C loss may ensue as carbon inputs to soils diminish.

Although the sampling shafts show no effect of deforestation on soil $\mathrm{C}$ and nutrient stocks, the network of ruts across the pasture landscape suggests a mechanism for potentially large soil loss at the scale of a hillslope. The resolution of this apparent contradiction can be found in the scale of our soil pits relative to the landscape. When digging soil pits on steep slopes, the sampling face is often (and in our case was always) located on the uphill section of the pit. Although this minimizes digging time, it increases the likelihood that the sampling face is cut into the downhill side of a rut (e.g., along the dashed blue line in Fig. S2). This profile location will have the least soil loss of anywhere in this heavily rutted landscape, thus it gives the most complete soil profile available in the pastures. However it also leads to an underestimate of the dramatic changes associated with grazing in this landscape. In our system, ruts average $13 \mathrm{~cm}$ deep and cover 45 percent of the hillslopes we measured, which translates into an erosion rate of $\sim 1.3 \mathrm{~mm} / \mathrm{yr}$ just from ruts. For comparison, long-term erosion rates determined by cosmogenic radionuclide analyses in forested watersheds at nearby Las Alturas station are $\sim 0.2 \mathrm{~mm} / \mathrm{yr}$ (S. Porder, unpubl. data). Our data are consistent with erosion as the dominant process by which these ruts are created, and the geomorphic literature on 'terracettes' and 'cowtours'. We performed two independent tests of the hypothesis that the ruts are created by erosion and compaction: (1) comparison of soils from the uphill and downhill portion of individual ruts; and (2) a calculation of expected rut soil $\mathrm{C}$ based on the geometry of the rut, the assumption that ruts had been formed by erosion, and compari- son to measured soil C. Both tests support the erosion hypothesis, although the $0-5 \mathrm{~cm}$ expected $\% \mathrm{C}$ data do not, suggesting compaction in these upper soils. As the upper $5 \mathrm{~cm}$ of soil can also be affected by topsoil washing downslope (which would increase and homogenize soil $\mathrm{C}$ in the very upper soil of the rut), we believe the $5-10$ and $10-15 \mathrm{~cm}$ data are more indicative of the true differences between the uphill and downhill edges of the ruts.

Our data suggest that $\sim 6 \mathrm{~cm}$ of soil have, on average, been lost from these pastures via erosion since deforestation ca 1960. Based on soil nutrient stocks in the upper $6 \mathrm{~cm}$, we estimate that since forest conversion $32 \mathrm{Mg} \mathrm{C} / \mathrm{ha}$, or $\sim 18$ percent of the total soil $\mathrm{C}$ stock to a depth of $1 \mathrm{~m}$ has been removed from the site and washed downstream. Similarly, $3500 \mathrm{~kg} \mathrm{~N} / \mathrm{ha}(18 \%$ of $1 \mathrm{~m}$ stock), $450 \mathrm{~kg} \mathrm{P} / \mathrm{ha}$ ( $9 \%$ of $1 \mathrm{~m}$ stock), and $2000 \mathrm{~kg} \mathrm{~K} / \mathrm{ha}$ (7.6\% of $1 \mathrm{~m}$ stock) have been lost. This translates into a rate of $\mathrm{C}$ and nutrient loss of $0.64 \mathrm{Mg} \mathrm{C} / \mathrm{ha} / \mathrm{yr}, 70 \mathrm{~kg} \mathrm{~N} / \mathrm{ha} / \mathrm{yr}$, $9 \mathrm{~kg} \mathrm{P} / \mathrm{ha} / \mathrm{yr}$, and $40 \mathrm{~kg} \mathrm{~K} / \mathrm{ha} / \mathrm{yr}$.

We suggest that these losses, rather than exports in beef or from decomposition, will drive the larger impact of deforestation on soil carbon and nutrient stocks in this wet, premontane landscape. Globally, the fate of eroded carbon (burial and storage vs. instream processing and $\mathrm{C}$ release to the atmosphere) is hotly debated (Lal 2003, Lal et al. 2004, Van Oost et al. 2007). Because we do not yet know the fate of this eroded soil C at Las Cruces, we cannot quantify whether rut-driven erosion in Las Cruces is ultimately a source or sink of soil C.

The importance of erosion in this landscape extends beyond the carbon cycle. The rapid loss of fertile topsoil may come to constrain pasture productivity around Las Cruces in the coming decades, as it has elsewhere (Hartemink 2006). Depletion of soil nutrients has significantly impacted global crop yields (Tan et al. 2005, Lal 2009), and we expect the losses observed at Las Cruces to lower pasture productivity given the much lower $\mathrm{N}$ and $\mathrm{P}$ found in the subsoil. Although $\mathrm{N}$ and $\mathrm{P}$ enrichment of topsoil relative to subsoil is a global phenomenon even in unfertilized settings Jobbágy \& Jackson 2001), N enrichment can occur naturally over the course of several decades (Davidson et al. 2007). In contrast, P enrichment by plant cycling can take tens of thousands of years (Porder \& Chadwick 2009). The P concentration in these pastures is $4-5$ times what is found in similar settings in the Amazon (where pasture productivity degrades over a decade or two), so it is no surprise that these pastures have remained fertile for over $50 \mathrm{yr}$. But the pace of cattle-induced soil loss, and the lower $\mathrm{N}$ and $\mathrm{P}$ concentrations in the exposed subsoil, suggests that productivity is likely to diminish under this management regimen in the coming decades. Although we caution against blanket extrapolation of our results given the limited spatial scale of our sampling, cattle ruts are ubiquitous in almost every steep pasture we have observed in southern Costa Rica (and indeed across much of the tropics). Thus, we suspect that this phenomenon may be an important one to consider in evaluating the soil carbon and nutrient effects of deforestation. 


\section{CONCLUSIONS}

In some ways, these data fit many well established patterns from the literature: soil carbon does not change with forest conversion to pasture, montane tropical soils are $\mathrm{C}$ rich relative to their lowland counterparts, and soil nutrient stocks are high on volcanic soils. The ubiquity of cattle ruts, however, both in Las Cruces and throughout the tropics, suggests that perhaps a focus on carbon and nutrients at the scale of a soil pit or soil core is not appropriate in this landscape. At the landscape scale, grazing animals are causing dramatic shifts in both $\mathrm{C}$ and nutrients, and the fate of that $\mathrm{C}$, and of pasture productivity in the longer term, will almost certainly be affected by this process. Although this study is only a start in quantifying the extent and impact of this largerscale landscape feature, we suspect it may well be important for our understanding of the effects of land use on tropical soil properties and management.

\section{ACKNOWLEDGMENTS}

We would like to thank Zak Zahawi and the staff of the Las Cruces Biological Station for their support in the field. This research was supported by the Andrew Mellon Foundation and NSF DEB 0918387 to S.P.

\section{SUPPORTING INFORMATION}

Additional Supporting Information may be found in the online version of this article:

TABLE S1. Soil carbon and nutrient concentrations for the $A$ and $B$ horizons at Las Cruces.

FIGURE S1. Site location in southern Costa Rica, and air photographs showing progressive deforestation from 1960-1980.

FIGURE S2. Photograph of ruts across a pasture hillslope and a schematic representation of how we quantified soil removal from these ruts.

Please note: Wiley-Blackwell are not responsible for the content or functionality of any supporting materials supplied by the authors. Any queries (other than missing material) should be directed to the corresponding author for the article.

\section{LITERATURE CITED}

Davidson, E. A., C. Neill, A. V. Krusche, V. V. R. Ballester, D. Markewitz, and R. De. O. Figueiredo. 2004. Loss of nutrients from terrestrial ecosystems to streams and the atmosphere following land use change in Amazonia. In R. S. DeFries, G. P. Asner, and R. A. Houghton (Eds.). Ecosystems and land use change, pp. 147-158. American Geophysical Union, Washington, DC.

Davidson, E. A., C. J. Reis de Carvalho, A. M. Figueira, F. Y. Ishida, J. P. H. B. Ometto, G. B. Nardoto, R. T. Saba, S. N. Hayashi, E. C. Leal, I. C. G. Vieira, and L. A. Martinelui. 2007. Recuperation of nitrogen cycling in Amazonian forests following agricultural abandonment. Nature 447: 995-998.
DeFries, R. S., T. Rudel, M. Uriarte, and M. Hansen. 2010. Deforestation driven by urban population growth and agricultural trade in the twenty-first century. Nature Geosci. 3: 178-181.

Fearnside, P. M. 1980. The effects of cattle pasture on soil fertility in the Brazilian Amazon: Consequences for beef production sustainability. Trop. Ecol. 21: 125-137.

Guo, L. B., AND R. M. GifFord. 2002. Soil carbon stocks and land use change: A meta analysis. Glob. Chang. Biol. 8: 345-360.

HarteminK, A. E. 2006. Assessing soil fertility decline in the tropics using soil chemical data. Adv. Agron. 89: 179-225.

Houghton, R. A. 2003. Revised estimates of the annual net flux of carbon to the atmosphere from changes in land use and land management 1850 -2000. Tellus B 55: 378-390.

Houghton, R. A. 2007. Balancing the global carbon budget. Annu. Rev. Earth Planet. Sci. 35: 313-347.

Jin, V. L., L. T. West, B. L. Haines, and C. J. Peterson. 2000. P retention in tropical pre-montane soils across forest-pasture interfaces. Soil Sci. 165: 881-889.

Jobbágy, E. G., And R. B. JaCKSOn. 2001. The distribution of soil nutrients with depth: Global patterns and the imprint of plants. Biogeochemistry 53: 51-77.

LAL, R. 2003. Soil erosion and the global carbon budget. Environ. Int. 29: $437-450$.

LAL, R. 2009. Soils and food sufficiency. A review. Agron. Sustain. Dev. 29: $113-133$.

Lal, R., M. Griffin, J. Apt, L. Lave, and M. G. Morgan. 2004. Ecology: Managing soil carbon. Science 304: 393.

MacDonald, G. K., E. M. Bennett, P. A. Potter, and N. Ramankutty. 2011. Agronomic phosphorus imbalances across the world's croplands. PNAS 108: 3086-3091.

McGrath, D. A., C. K. Smith, H. L. Gholz, and F. de Assis Oliveira. 2001. Effects of land-use change on soil nutrient dynamics in Amazônia. Ecosystems 4: 625-645.

Neill, C., J. M. Melillo, P. A. Steudler, C. C. Cerri, J. F. L. de Moares, M. C. Piccolo, And M. Brito. 1997. Soil carbon and nitrogen stocks following forest clearing for pasture in the southwestern Brazilian Amazon. Ecol. Appl. 7: 1216-1225.

Porder, S., AND O. Chadwick. 2009. Climate and soil-age constraints on nutrient uplift and retention by plants. Ecology 90: 623-636.

Powers, J. S., M. D. Corre, T. E. Twine, and E. Veldkamp. 2011. Geographic bias of field observations of soil carbon stocks with tropical land-use changes precludes spatial extrapolation. PNAS 108: 6318-6322.

Powers, J. S., AND E. VeldKAmp. 2005. Regional variation in soil carbon and $\delta^{13} \mathrm{C}$ in forests and pastures of northeastern Costa Rica. Biogeochemistry $72: 315-336$.

Raнm, D. A. 1962. The terracette problem. Northwest Sci. 36: 65-80.

Rhoades, C. C., G. E. ECKert, and D. C. Coleman. 2000. Soil carbon differences among forest, agriculture, and secondary vegetation in lower montane Ecuador. Ecol. Appl. 10: 497-505.

SAncheZ, P. A. 1976. Properties and management of soils in the tropics. John Wiley and Sons, New York. 618p.

SANCHEZ, P. A. 2002. Ecology: Soil fertility and hunger in Africa. Science 295: 2019-2020.

Schedlbauer, J. L., And K. L. Kavanagh. 2008. Soil carbon dynamics in a chronosequences of secondary forests in northeastern Costa Rica. For. Ecol. Manage. 255: 1326-1335.

Serrão, E. A. S., D. Nepstad, and R. Walker. 1996. Upland agricultural and forestry development in the Amazon: Sustainability, criticality, and resilience. Ecol. Econ. 18: 3-13.

Smaling, E., S. M. Nandwa, and B. H. Janssen. 1997. Soil fertility in Africa is at stake. In R. J. Buresh, P. A. Sanchez, and F. Calhoun (Eds.). Replenishing soil fertility in Africa, pp. 47-61. SSSA, Madison, WI.

Smith, P., D. Martino, Z. Cai, D. Gwary, H. Janzen, P. Kumar, B. McCarl, S. Ogle, F. O’Mara, C. Rice, B. Scholes, O. Sirotenko, M. Howden, 
T. McAllister, G. Pan, V. Romanenkov, U. Schneider, and S. TowPRAYOON. 2007. Policy and technological constraints to implementation of greenhouse gas mitigation options in agriculture. Agric. Ecosyst. Environ. 118: 6-28.

Tan, Z. X., R. Lal, and K. D. Wiebe. 2005. Global soil nutrient depletion and yield reduction. J. Sustain. Agr. 26: 123-146.

Trimble, S. W., And A. C. Mendel. 1995. The cow as a geomorphic agent-a critical review. Geomorphology 132: 233-253.

Van Oost, K. T., T. A. Quine, G. Govers, S. De Gryze, J. Six, J. W. Harden, J. C. Ritchie, G. W. McCarty, G. Heckrath, C. Kosmas, J.
V. Giraldez, J. R. Marques da Silva, and R. Merckx. 2007. The impact of agricultural soil erosion on the global carbon cycle. Science 318: 626-629.

VeldKamp, E. 1994. Organic carbon turnover in three tropical soils under pasture after deforestation. Soil Sci. Soc. Am. J. 58: 175180.

Veldokamp, E., A. Becker, L. Schwendenmann, D. A. Clark, and H. SChulte-Bisping. 2003. Substantial labile carbon stocks and microbial activity in deeply weathered soils below a tropical wet forest. Glob. Chang. Biol. 9: 1171-1184. 